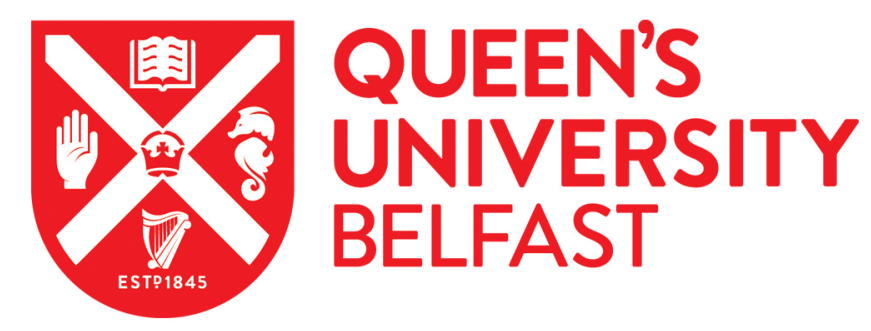

\title{
Space and Place: Lessons from National School Buildings in the North of Ireland
}

McKerr, L., Graham, B., Sloan, B., \& Murphy, E. (2017). Space and Place: Lessons from National School Buildings in the North of Ireland. International Journal of Historical Archaeology, 21(4), 785-805. https://doi.org/10.1007/s10761-017-0404-7

\section{Published in:}

International Journal of Historical Archaeology

\section{Document Version:}

Peer reviewed version

\section{Queen's University Belfast - Research Portal:}

Link to publication record in Queen's University Belfast Research Portal

\section{Publisher rights}

(C) 2016 Springer.

The final publication is available at Springer via http://dx.doi.org/10.1007/s10761-017-0404-7

\section{General rights}

Copyright for the publications made accessible via the Queen's University Belfast Research Portal is retained by the author(s) and / or other copyright owners and it is a condition of accessing these publications that users recognise and abide by the legal requirements associated with these rights.

Take down policy

The Research Portal is Queen's institutional repository that provides access to Queen's research output. Every effort has been made to ensure that content in the Research Portal does not infringe any person's rights, or applicable UK laws. If you discover content in the Research Portal that you believe breaches copyright or violates any law, please contact openaccess@qub.ac.uk. 


\title{
Space and Place: Lessons from National School Buildings in the North of
}

Ireland.

\author{
Lynne McKerr ${ }^{1}$ \\ Barbara Graham2 \\ Brian Sloan3 \\ and \\ Eileen Murphy4
}

Suggested running head: Space and Place: National School Buildings in the North of Ireland

1

School of Social Policy, Education and Social Work Queen's University Belfast, 69-71 University Street, Belfast BT7 1HL, Northern Ireland. Telephone=44 (0) 2829541991. E-mail address 1.mckerr@ qub.ac.uk 2

Independent researcher, Rostrevor, Co. Down, Northern Ireland. E-mail address barbaragrhm@gmail.com 3

Centre for Archaeological Fieldwork, School of Natural and Built Environment, Queen's University Belfast, Belfast BT7 1NN, Northern Ireland. E-mail address b.sloan@qub.ac.uk

4

Archaeology and Palaeoecology, School of Natural and Built Environment, Queen's University Belfast, Belfast BT7 1NN, Northern Ireland. E-mail address eileen.murphy@qub.ac.uk 
Abstract: Integrated schooling is currently promoted in post-conflict Northern Ireland, but an earlier attempt to establish secular education in Ireland during the nineteenth and early twentieth centuries - the Irish National Schools system - is often forgotten. A preliminary study of former National Schools indicated architectural differences between rural and urban buildings, possibly linked to the expression of divergent cultural and religious traditions in conflict with the reforming principles of the national system. This paper uses archaeological and anthropological perspectives, including the first recorded excavation of a National School in Northern Ireland, to examine their past and current significance for education, identity and, place. Keywords: secular education, school buildings, identity, Ireland.

During the nineteenth and early twentieth centuries, a bold reforming experiment in secular education was undertaken in Ireland (Akenson 1970), a country with a lengthy history of religious and political division. With the introduction of the National Schools system in 1831, Catholic and Protestant children were to be educated together as equals, for the first time, in local schools subsidized by government but sponsored by the local community. The system operated for some 90 years before it ceased in Northern Ireland following Partition in 1921. A large number of former National Schools still exist, although in varying states of repair, and this paper is the continuation and development of research into clusters of such buildings in rural County Fermanagh and the city of Derry (McKerr and Murphy 2014). Although most of the remaining buildings are no longer functioning as schools, it became apparent during the course of this research how highly regarded many were in the present-day community. Given their prominence in local memory and in the landscape, it is surprising how little attention they have attracted from archaeologists and anthropologists.

In this paper we hope to begin to redress this situation by expanding on the original study by McKerr and Murphy, looking at a wider number of former schools, exploring the idea of the 
school itself as a frame for behavior and investigating the social life of buildings over the course of time. Two previous $19^{\text {th }}$ century school sites have been excavated in the Republic of Ireland. Dillon's Bridge National School in County Meath, was open from 1860 -1940 (Rathbone 2007), although local historians date the closure to 1957 (Navan and District Historical Society, 2016; not noted as a National School in the excavation report, local history records it as such). It measured 47 feet 10 inches by 21 feet 8 inches (14.6 m x $6.6 \mathrm{~m})$, divided into three rooms. 'The Old Bog School' at Rockforest, Co. Tipperary dates from the $19^{\text {th }}$ century but was abandoned around 1900; the building was 36 feet 1 inch $\times 16$ feet 9 inches $(11 \mathrm{~m} \times 5.1 \mathrm{~m})$ and although the gable walls and one side wall remain, no information on the internal organisation of the building is available (Hardy 2007). Both sites were explored during roadworks and neither was investigated as part of a community project. In this study, the documentary and oral history records are, for the first time in the north of Ireland, enriched by information from the excavation of a National School site at Arney, County Fermanagh, which allows a unique insight into both the past and present impact of the building on the local community. The activity at the site of the former National school engaged the present community (of all ages) and can be seen as providing the space for constructive dialogue around memories of the past (Little and Shackel 2014) which also challenges more contemporary narratives about education and society -- an ethnographic study was a central element of the community project. This does however remain a preliminary study; there is no definitive list of extant National School buildings and, as part of ongoing research, the present study examines a number of exemplars, both urban and rural, from Counties Derry, Fermanagh, and Down.

\section{Background}


In 1831, the Irish National School system was introduced - the result of a review of education following many years of inequality in access for those who were not members of the Established Church (referred to at the time as "Protestants"; elsewhere known as Episcopalians or Anglicans). In the past there had been considerable government support in terms of both endorsement and funding for schools founded or managed by religious organizations, the so-called "Bible schools", which provided education within a Protestant context. These schools were seen by non-conforming clergy and parents (that is, those who were not members of the established religion, the Church of Ireland) to have an openly proselytizing agenda, which discouraged the attendance of children of other denominations (Robins 1987). As a result, these families sought out alternatives known as "hedge schools," less formal and sometimes peripatetic classes for children from Catholic and Dissenting Protestant families, usually held in barns or small dwellings. During the seventeenth and eighteenth centuries, these were technically illegal, although by the early nineteenth century they were able to operate fairly openly (Dowling 1968; Mason 1814) - the teaching standards were highly variable, ranging from excellent to abysmal (Akenson 1970; Dowling 1968; Porter 1871[1999]).

The report published by the Irish Education Inquiry in 1825-26 indicated that the existing piecemeal system of education was totally inadequate, and that the previous unequal method of funding was no longer appropriate (Markus 1993; Raftery and Relihan 2012). Given the past history of religious intolerance and civil strife in Ireland, the National system had as its central aim that all children would be educated together in local schools, following a common secular curriculum but with separate religious instruction (Akenson 1970). Reformative values which were to be instilled through this new system included those of "peace and tolerance" (Hyland 1986, pp. 250-251) and religious emblems and prayers were forbidden during the periods of secular education (Hyland 1986). Academic standards and teacher 
training were regularized, and subject to government inspection. Many of the original applications for grants to build or maintain a school are archived at the Public Records Office for Northern Ireland (PRONI). It was initially intended that the schools should be sponsored or supported by both Catholics and Protestants of some standing within the district, and their signatures are added in designated areas of the application forms. Education for all was hardwon, and even during the Great Famine, and its dismal aftermath of emigration, an examination of school statistics (Akenson 1970) shows a steady growth in the number of schools in operation, with an average increase in school numbers of just over 200 per year between 1845 and 1851. Of course, schools could close as well as open so this is not a complete picture, but even in such difficult times, schools were being established as people looked to the future for their children. By 1870 some 2,500 schools had been founded in what was then the northern Province of Ulster, and by 1900, there were 8,684 National Schools throughout Ireland, attended by 478,224 pupils (Hyland and Milne 1987, p. 193). Ireland was partitioned in 1921, with six of the original nine counties of the province of Ulster forming the new state of Northern Ireland. After Partition, the schools in the north remained in use, although now under the control of the new Ministry of Education, which permitted some to become faith schools alongside a state system. The vast majority of faith schools formed were Catholic and this has resulted in what is in effect a binary education system (Bardon 2005; McGlynn 2009). Protestant children generally attend "Controlled" state schools, and Catholic children attend "Maintained" voluntary schools, which are partly funded and managed by the Catholic Church. There are small numbers of other denominational voluntary schools (mostly at the secondary level) and an increasing number of integrated ones, but the majority of children continue to attend religiously divided schools.

\section{External appearances and internal organization}


There is currently no register of surviving National School buildings in Northern Ireland and the present study investigated a purposive sample of 36 National Schools, selecting areas where some schools had previously been identified, in Counties Derry, Down, and Fermanagh in Northern Ireland (see Figure 1). The schools were selected using the authors' local knowledge and also by a web search using the term 'National Schools' specifically for two large towns in County Down, Banbridge and Holywood. Where possible, these were verified by consulting the register of records for National Schools currently held by PRONI which are listed by parish (PRONI 2015). Of the 36 schools selected, six (one in Holywood and five in Banbridge) could not be located. Tables I and II list the 30 extant schools, their size, location with respect to any church, and present condition.

\section{Rural Schools: initial findings}

A total of 13 rural National School buildings were included in this study, and are described briefly from external inspection in Table I. The rural schools shown in Figure 2 (Lisded, Carrickbeg, Tullyholvin, and Rossinure More) were the subjects of the original study by McKerr and Murphy (2014). They are very similar, built from local stone in a vernacular style and all have just one room, and one entrance. There were many such small schools in rural areas, and each townland (the smallest unit of a parish division) could have had at least one school. This western region of County Fermanagh is mountainous, and given the dispersed nature of settlement in the area, young children could not be expected to walk any great distance. Roll books for Carrickbeg and Tullyholvin schools indicated that many children started school at six or seven years of age (McKerr and Murphy 2014), somewhat later than the present legal age-range for commencing school, which is between four and five years. 
Of the four schools illustrated (numbers 1-4 in Figure 1), only Carrickbeg could be said to be associated with a church as it sits in the grounds of Boho Catholic chapel, although the register indicates that Protestant children attended the school ( McKerr and Murphy 2014). Oral history recollections from former pupils of Carrickbeg in the 1930s and 1940s (McKerr and Murphy 2014; McKerr 2010) indicate that classrooms were organized by attainment sets, roughly correlated with age, with infants (the youngest classes, with children usually aged from three to six years) furthest from the door and closest to the teacher's desk. There was no separate playground for boys and girls. The only formal spatial gender separation was in the use of the privies, although there was a division of labor whereby the senior girls were expected to tidy the class or fetch tea for the teacher, while the older boys had to empty the dry toilets (McKerr and Murphy 2014).

\section{Urban and village schools}

The original study has been expanded to include urban and village schools from Counties Down and Fermanagh as well as further schools from Derry City (see Table II). It can be seen from Figure 3 that, compared with the original sample of rural schools, the urban and village schools illustrated are built in very distinctive architectural styles, often very ornate, with different external finishes - brick, dressed stone, or stucco render. In addition, many of these schools are closely associated with a specific church. Rowan (1979) remarked on what he considered to be the 'competitive' architectural variation between Victorian churches of different Christian religions in Derry City. Of the 17 schools listed in Table II, only three (18\%) were not associated with, or located close to, a church. It seems that in these areas of

Ulster, urban and village churches were clearly establishing control over education and making definitive statements about identity in the building styles, association of names and physical placement of "their" schools, despite the secular aims of the National system which 
was -- at least in part -- funding them. A very visible exception to this is the ornate Sullivan National School (originally separate boys' and girls' schools housed in the same building) in Holywood, County Down, specifically built for secular education by distinguished educationalist, Dr. Robert Sullivan (Figure 3, F). This school existed alongside two other National Schools designated "Parochial" (Church of Ireland) and "R.C." (Roman Catholic; Ulster Towns Directory 1910). The latter was founded by religious historian Monsignor James O’Laverty, but was demolished in 1977 (Auld 2002).

Larger urban populations allowed for more sharply delineated sectarian catchment areas, while wealthy urban churches (and philanthropists) could set themselves apart by creating distinctive "landmark" buildings, resulting in an accentuation of difference. By allowing the churches to manage schools in this way, while providing funding for them to offer secular education, the National system was in effect setting itself up for failure. With the tensions induced by the growing power of the Catholic Church, education became an arena for open competition. Schools became increasingly denominational in character (Cohen 2000) and, by 1900, schools with "mixed" enrolments were in the minority throughout Ireland (Akenson 1970). In effect, schools 'were functioning overwhelmingly along confessional lines' (Walsh 2008, p. 653), which of course defeated the original reformative purpose of the National system.

The size of these urban and village schools also allowed opportunities for increased differentiation in age sets and gender between pupils. For example, the majority of the schools illustrated in Figure 3 (and half of the schools listed in Table II) have an upper storey, and a majority of those visited originally had separate entrances, one for boys and another for girls and "infants", the youngest class. Within the schools, some surviving plans indicate that originally, apart from infants who appear to have been regarded as ungendered, boys and girls had separate classrooms, leading from the separate entrances. Access analysis of these floor 
plans indicated that girls and infants occupied deeper spaces within the school with more limited movement between classes than boys (McKerr and Murphy 2014). This segregation was maintained in the playgrounds as well, with "infants" of both sexes consigned to the female sections of the school, perhaps as a result of contemporary Victorian ideology which perceived ungendered infants and girls as inherently more vulnerable than boys (Markus 1993), and whose childish innocence (i.e. with respect to sexual behavior) had to be somehow protected (Weeks 2012). When you consider that many of these children came from working class areas where entire families lived perhaps in one or two rooms, with an almost total lack of privacy, and that boys and girls could play together on the streets, this emphasis on 'protecting' girls and infants appears to be no more than the exaggerated modesty commonly associated with so-called Victorian values (Hall 2013, p. 10). Although the oral history participants from the Derry schools pictured in Figure 3 indicated that the use of separate classrooms had disappeared by the 1930s and 1940s, boys were still segregated from girls and infants at playtimes, and this was reinforced by siting the toilet facilities within separate playgrounds (McKerr and Murphy 2014).

\section{A rural-urban divide?}

Initially it appeared that rural schools placed less emphasis on separating boys from girls. This could be interpreted as a function of size, a constraint imposed by the costs of building and maintaining schools in what were often impoverished communities; or as a natural evolution from the small informal 'hedge-schools'(McKerr and Murphy 2014). Further investigation of rural schools indicated that the situation was not quite so simplistic (Table I and Figure 4).

Clearly, larger, ornate buildings did exist in the countryside, such as Annsborough School in County Down (Figure 4, E) with its Gothic windows and unusual symmetrical projecting 
bays, and the school at Lislea, County Derry, with separate entrances and classrooms for boys and girls, which has a central dwelling house dividing them (Figure 4, C). Movanagher school, also in County Derry, which is in a similar "Tudoresque" style to Lislea (Figure 1, 7) was originally built by the London-based Mercer's Company which had been granted major landholdings in the seventeenth century (Curl 2000). Even relatively small schools such as Crossroads in Kilrea, Ballynease in Bellaghy (both County Derry), and Killowen in County Down, could have two entrances (see Figure 4). It seems then that schools were not constructed to a generic plan, but were built in styles which reflected the individual cultural contexts and the values of the communities they served, and which transmitted these values to subsequent generations.

\section{Buildings as a frame for behavior}

Given that these were purposeful public buildings designed to influence social behavior, how then did they act as a frame or a setting for such behavior, and how can they be said to be connected to notions of cultural values and identity? The layout of the schools in terms of the gender divisions arguably reflects the contemporary demarcations and segregations in wider society at the time. But it is important to perhaps go beyond just a generalized notion of segregation and consider how material culture, not just the buildings but also their contents, may affect, direct, and encourage behaviors.

Daniel Miller (2010, pp. 49-51) in considering a theory of frames, describes material objects as a setting. They inform us of what is expected, how to behave, and "make us aware of what is appropriate and not appropriate." Whether a place of worship or a schoolhouse, or an event such as a wedding or a funeral, the associated materiality of a place or event is impressed on our cultural knowledge to elicit a particular response. Similar to Bourdieu's (1977) theory of habitus there are learned and automatic reactions to a setting occasioned by material objects. 
Materiality is part of the whole but the school buildings, even if devoid of much beyond a few benches, operated also, through their architectural design, as a psychological frame to determine behavior. Events are framed by different types of materiality and work most effectively, according to Miller, when we do not actually notice them, but rather, just accept them. This "humility of things" (Miller 2010, p. 50) can also be applied to the schoolhouse and its external and internal material manifestations. Thus, a child entering a National School is channeled initially through a particular entrance, towards specific places in the room or rooms, and the material objects of desks, blackboards, books and pencils, slates or pens, work subconsciously to instill particular behaviors appropriate to the setting. Things are telling a story and also directing behavior. They have a psychological and psychosocial effect.

Such responses to places and things may be seemingly involuntary, as if the place is acting on the person. Coleman (1998, p. 177) provides an apt illustration of this when he reminds us of how a child in the Great Blasket Islands, County Kerry, described her first impressions of school in 1870: "All the children trooped in and each sat on its own bench...mute enough now" (Peig Sayers, cited by Coleman 1998, p. 177). This study draws on autobiographical accounts from the nineteenth and early twentieth century to "examine the diverse responses of their narrators as children to the national schools..." (Coleman 1998, p. 179). Through the memories of that early pupil, we catch the essence of how the structure of the building and the arrangement of things inside framed behavior. The responses of these early pupils on how the buildings shaped behavior are echoed in the contemporary memories of those who attended former National Schools over the past two generations. One woman from County Fermanagh who took part in the ethnographic project at Arney remarked, "We had to behave in school then. Teachers took no nonsense!"

Anthropological interest in the house as both dwelling and a place of socialization provides a useful conceptual framework with which to analyze and understand the spatiality of the 
schoolhouse and its materiality. Bourdieu (1977, p. 89) compared the house to a book "in which is inscribed a vision and a structure of society and the world". The building and its contents act on us as we also act on it; "Moving in ordered space the body reads the house which serves as a mnemonic for the embodied person" (Carsten and Hugh-Jones 1995, p. 2).

Those normative values we ascribe to schools of good behavior -- attention to learning and recognizing the authority of the teacher -- were coupled with wider cultural and local values. These schoolhouses held particular resonance in their local setting, their place in the landscape, and it is these interwoven connections to place and localized culture, identity, and kinship that are prevalent in the narratives of those who attended the schools. These connections are explored further in the case study of a community involved in the excavation in 2014 of a former National School -- Arney, in County Fermanagh.

\section{Case Study: Arney National School}

Arney is a small village in south-west County Fermanagh, in the parish of Cleenish (see Figure 1). It is connected to a much wider rural population, some of whom reside in the neighboring parish of Killesher. In 2013 Killesher Community Development Association and Cleenish Community Association were jointly awarded a grant from the Heritage Lottery Fund for their local history project, Battles, Bricks and Bridges. As part of the development of the project, a community excavation was undertaken to explore the site of a former National School beside the historic seventeenth-century Arney Bridge. The area around the bridge was said to be the original site of Arney village, formerly the center of a small-scale brick-making industry during the nineteenth and early twentieth centuries. The excavation was undertaken by members of the Centre for Archaeological Fieldwork (CAF), Queen's University Belfast, with support from Queen's University Belfast postgraduate students, the 
Northern Ireland Environment Agency (NIEA), and the Cleenish and Killesher community groups. It took place during the period 31 March - 15 April 2014 and involved not just the archaeologists but an enthusiastic team of local volunteers, including members of an older generation who had attended the local primary school in the 1950s and 1960s, and the younger generation who attend the present-day Arney Primary School.

\section{The history of Arney National School}

The schoolhouse is documented on the first edition six-inch Ordnance Survey (OS) map dating to 1835 , which shows it to the immediate south-east of the bridge (Sloan 2014). The original applications for grant aid for two teaching positions through the National Schools system are archived in PRONI and indicate that the then-present school was established in September 1847 and that a grant for a teacher was applied for in September 1849 (ED/1/22/13). These also confirm that the building had been in use previously, as an earlier application in 1847 was refused because the building was in poor repair. The successful application of 1849 contained valuable information on the construction of the existing school building. Unsurprisingly given the local industrial context, it was built of brick and lime mortar, and the roof was thatched. The dimensions of the school room were stated as 19 feet by 14 feet 3 inches by 6 feet 10 inches $(5.79 \mathrm{~m} \times 4.34 \mathrm{~m} \times 2.08 \mathrm{~m})$. Overall, the school measured 37 feet by 15 feet by 7 feet $(11.28 \mathrm{~m} \times 4.57 \mathrm{~m} \times 2.13 \mathrm{~m})$, the additional space taken up by the teacher's residence, occupying "two rooms attached which communicate with the school room" (ED/1/22/13). James Dolan, aged 22, was named as the schoolmaster, and there were 40 males and 20 females on the roll. Of these, 20 children were admitted free as there were allowances made for the poorest families; the rest paid $£ 3$ per year. School hours in general were from $9 \mathrm{am}$ until $3 \mathrm{pm}$, which changed to $10 \mathrm{am}$ until $3 \mathrm{pm}$ during winter to allow for safe journeys in the colder, darker mornings. Religion was to be taught on Saturdays. 
Classroom furnishings consisted of three desks, four stools, and three forms (long benches); the school was "sufficiently ventilated and warmed" and in a "tolerable" state of repair (ED/1/22/13). The 1849 application also noted that the sponsor of the school was the Parish Priest, Father Francis Mason, and the District Inspector signed a declaration on the form that he had consulted with the clergymen of all denominations in the district, none of whom objected to the school.

By 1851, the date of the second application, this time for a work mistress to teach the girls sewing (ED/1/22/59), the number of pupils on the roll had risen to 52 males and 50 females. The school now had two classrooms, "the smaller one" for the work mistress measuring 17 feet 5 inches by 14 feet 3 inches by 6 feet 10 inches $(5.3 \mathrm{~m} \times 4.34 \mathrm{~m} \times 2.08 \mathrm{~m})(\mathrm{ED} / 1 / 22 / 59)$, presumably having incorporated what were formerly the previous schoolmaster's living quarters. This teacher was Mrs. Anne Murray, who was employed to teach needlework every day from 12 noon to $3 \mathrm{pm}$, except Saturday. Extra furnishings for this class included a "convenient work table", a chest, and drawers (ED/1/22/59).

By the time of publication of the third edition OS map of the area (dated 1905-7), the schoolhouse was no longer present (Sloan 2014), suggesting that by 1907 it had been demolished. This confirms information from local residents that it was replaced in the early twentieth century by the more modern Arney Primary School located a short distance away. Many of the local residents interviewed had attended Arney Primary School until it too was replaced in 1964 by a new school in the present-day Arney village.

\section{Excavation summary}

Three areas were selected for investigation during the community archaeological works at Arney (see Figure 1 for location). Trench One was placed in a field to the immediate south- 
east of the Arney Bridge to determine if there were archaeological features and deposits associated with the National School building, while Trenches Two and Three were located within a row of vernacular cottages approximately 50m to the south-west of, and on the opposite side of the road from, Trench One. The full excavation report (Sloan 2014), from which information in this summary section was drawn, has been filed with the NIEA. Trench One measured $10 \mathrm{~m}$ in length (east/west) by $3 \mathrm{~m}$ (north/south) and was excavated to the surface of the natural subsoil. Excavation revealed features associated with the school building, including the remains of the front and rear brick walls and a beaten clay floor (see Figure 5). Other features uncovered were a drain to the rear of the structure and what may have been a rubbish pit associated with the school. Artifacts recovered during the excavation of this trench included fragments of ink-wells, ruled writing slates and styli, a variety of postsixteenth-century pottery sherds, as well as a coin, which may have been an early Victorian penny although it was too abraded to determine the date. Activities identified archaeologically, that post-date the school, include the insertion of a field drain and platform of large rocks, which could have provided a firm footing for a previous entrance into the field. Following the identification, excavation, and recording of the features in this trench, it was manually backfilled and the area returned to its original appearance. Throughout the excavations the project was open to the public, and this proved to be very popular, with many participating in the excavation. On two open days, children from the present-day Arney Primary School attended and they took part enthusiastically in the investigation of the site. The relative paucity of artifacts and the absence of much of the former materials from the school are indicators both of the deliberate dismantling of the school building, and the relative poverty and resultant resourcefulness of the inhabitants of the area in re-use of materials. It is likely that repairs or additions to nearby dwellings re-used the school house brick --Trench 3 on the opposite side of the road revealed a brick floor in a cottage, which 
was not typical of the period, as other floors were beaten earth, tiles, or stone slabs. Functional school furnishings and equipment would have been removed to the new premises. The pattern of relocation and re-use of materials at Arney is in many ways typical of the site formation processes of rural North American school houses (Beisaw 2009, pp. 55-56), where exploration of such sites is much more frequent. Excavations of these North American buildings have indicated that both the patterns of deposition (in yards, privies and sub floors), and the assemblages themselves, are significant as they can indicate the range of activities and intentions (social as well as educational) which were occurring at the time (Beisaw 2009, pp. 58-59; Rotman 2009, pp. 73-80). The sherds of post-sixteenth century pottery recovered at Arney are interesting; considerable quantities of 'modern china' sherds were also recorded at the 'Old Bog School' in Tipperary (Hardy 2007). It is possible that at Arney, they may represent domestic rather than "institutional" detritus from the period when it is known the school house had an attached dwelling for the master. However, in the past children would have played with such fragments; the Ulster Folk and Transport Museum has an archived photograph of two small girls playing "wee shop" with broken crockery arranged on a wall (McKerr 2010), and it is also possible that children intentionally brought pieces of broken pottery from home to school.

\section{Culture, identity, kinship: modern day Arney}

The project at Arney centers on community involvement and draws on a localized sense of place and history that is woven into everyday stories and narratives. The ethnographic project was undertaken in conjunction with the archaeological investigations in order to explore the impact of the National schools through contemporary oral histories. The interviews (twelve in total) undertaken with former pupils of Arney National School provided an insight into the social and cultural significance of the school and provided an opportunity to connect lived 
experiences of the school system. The memories of many of these pupils also provides us with accounts of the materiality of the building and its contents, furnishings of the classrooms, the daily routines of school children, and affords an understanding of how and why Arney school and its history plays a central role in people's sense of place, identity and belonging. The interviewees, both male and female, ranged in age from 60 to 86 years old, and the conversations during this project spanned reminiscences from the early 1930s until the 1960s. Walking around the excavation site or strolling with neighbors in the area the talk turns to people who lived nearby, what they did, their family ties, their descendants. Their social place and the physical place are inextricably linked in a sense of identity that pervades relationships and draws on enduring kinship connections. There is an interweaving of place and people; old houses long abandoned are set once again within that context of place, kinship and local culture. While local people do not remember this first school they do remember its replacement, just half a mile away, which opened in the first decade of the 1900s. Called then Arney Primary School, it holds a special place for those who attended. The memories are social in nature, and reveal a wealth of information relating to everyday school-going.

Tommy, now in his 80 s, remembers that his family supplied the milk for the school. The youngest of his siblings to attend the school, he talked of how the churns would be brought down by cart and left outside the school. Other former pupils remember how, on May Day, they were allowed to go to school in their bare feet. They talk of the friends they called for on the way to school; the minor transgressions of schoolmates; whose family supplied the coal for the fire; the boys who had the job of cleaning out the toilets, and the going home with delays along the way to play or explore.

In describing their experiences the former Arney Primary School pupils pepper their reminiscences with references to places in the landscape along their routes to school and to 
the people whose houses they passed as they made their way to school. One man remembered his walk across the fields and the companions he called for along the way: "I used to call for these two sisters to take them to school with me. It was a little detour but I did it there and back."

The reminiscences of the Arney pupils are interwoven with connections made to the wider rural community. Their stories provide an insight into the cultural values and social life of the school and its impact on pupils in their hours away from formal education. Rotman (2009, p. 72), in an investigation of a nineteenth-century schoolhouse in Indiana, reminds us that: "as one of the few social institutions which rural people encountered daily, the common school both reflected and shaped a sense of community." The internal architecture and materiality of the National schools in Ireland, similar to Rotman's American school, can reveal community attitudes and cultural values (2009, p. 81). The former Arney pupils attest to these by describing the emphasis put on gaining an education and on good order in the classroom; reinforced by the formal layout of benches and desks in the schoolroom. Schools were sites of socialization of children "for the roles they would play as adults in larger society" (Rotman 2009, p. 60). The gender separation evidenced by separate entrances and toilets, translated also to gender specific artefacts (Rotman 2009, p. 73).

These former pupils also remember how, up until the onset of the Troubles (thirty five years of ethno-nationalist violence in Northern Ireland between 1969 and 1994), their school remained inter-denominational. "It was the local school" said one man. "And everybody went to it. It's a pity that changed."

The connection to locality is inscribed in reasons given for attending a particular school. Some are practical: "It was the nearest school." Other reasons reveal attention to a continuity of practice within a townland that is interwoven with ties of kinship and a sense of identity to 
place: "Well, my mother went there"; "My grandparents went to the school"; "Everyone hereabouts attended the school."

Often the nearest school was also the school attended by parents and grandparents. Sometimes a school was selected on the basis of the reputation of the teacher: "If your parents wanted you to do well and maybe go on with education they would send you where the teacher got good results." These reasons often cut across denomination; even when a school may have been taken over by one church or another, that sense of place and loyalty to townland, neighbors, and kin, dominated. The school was viewed as an integral part of the local culture where schooling was holistic -- practical as well as academic.

The fondness displayed by the rural school goers for their old schools is echoed also in urban areas. One woman remembers how her mother talked of the National School she attended in Belfast. A large school, it had separate entrances for boys and girls, and the day was punctuated by changing classrooms for different subjects.

"Every 40 minutes they changed classes to a different teacher, the teachers didn't move. They all lined up to music ... every room had a piano and every teacher played ... and marched out in an orderly line to the next class for a different subject. My mother would have started school around 1919 so she was really being taught by Victorians! She remembered her school with great fondness and said the National Schools provided a very rounded education ... you really got an old fashioned classical education and that sense of order. Diversity and enquiring stayed with her all her life. She left school at 14 but could still do maths better than me, had read more, and certainly knew a lot more about music than I could ever hope to learn! She loved her school."

\section{The social life of a school}

The National Schools tell us about the history, identity and senses of place for people in a 
given locality. They do so through not just their architecture and archaeology, but through contemporary narratives of place and memories of those who attended these schools; thus retaining a social life of things (Appadurai 1986). Oliver (1969, p. 26) suggested that the study of vernacular buildings required also a study of the society that built them, used and reused them. He was concerned with the anthropology of buildings, of the people who inhabit them and with the interrelations between buildings, people, and ideas (Oliver 2006). Vellinga (2014) noted that for Oliver the cultural background of the builders and inhabitants were of fundamental importance in understanding the architecture concerned:

"It is one thing to recognize vernacular buildings as a source of delight and also of inspiration...But to understand how they came about, to comprehend, at least in part, what is of significance in the built forms of a given community within that community itself, to learn what its own priorities might be, the function of its built forms, of symbolic structure and the hierarchies of enclosed spaces - all this requires that the student of vernacular building gives his attention to society" (Oliver 1969, p.26). Drawing on his concerns we can, in examining the memories of those who attended the schools, the descriptions of the spatial organization inside and out and the associated stories of people and activities, attest to these buildings as being a locus for socialization. As Gieryn (2002, p. 35) has argued: "Buildings stabilize social life. They give structure to social institutions, durability to social networks, persistence to behavior patterns." Yet he reminds us that buildings "stabilize imperfectly" (2002, p. 35) -- many fall into ruin, are destroyed or refashioned into other places with other uses.

“Buildings don't just sit there imposing themselves. They are forever objects of (re)interpretation, narration and representation -- and meanings or stories are sometimes more pliable than the walls and floors they depict. We deconstruct buildings materially and semiotically, all the time" (Gieryn 2002, p. 35). 
The (re)interpretation of the National Schools buildings are evidenced throughout the countryside in their material reuse or abandonment (see below). But as a symbol of a reforming agenda their ethos and operation was also resisted from their inception by dissenting voices, both individual and institutional. One example was a letter published in Dublin to one of the Commissioners of the National Board of Education (Booker 1935, pp.116). The author, a clergyman, had built a school for the poor of his parish with equal numbers of Protestant and Catholic children attending. The only religious input into the school days was a short New Testament reading at the close of classes, something to which neither denomination objected. He complained that if he brought his school under the National Board system he would then have to give up part of the school day, to allow Catholic clergy onto the premises to teach religion and that daily bible reading would have to stop. This was a microcosm of powerful resistance from first the Presbyterian Synod of Ulster (Cohen 2000, p. 52) and then the Anglican and Catholic Churches who all won concessions from the National Board of Education to gain more control over their local schools. Cohen (2000, pp. 52-54) argues that Protestants objected from the start and concessions were made in order to prevent the system from collapsing before it had begun. In an examination of National Schools in Tullylish, County Down, in the second half of the nineteenth century, she shows how (as Walsh 2008 notes above) the efforts of both individual actors and institutions "worked to support or at times contradict the powerful drift towards denominationalism in the parish" (Cohen 2000, p. 69). Yet, despite the choices of parents whose choice of school for their children was "often, but not always, guided by denominationalism" (Cohen 2009, p. 69) the work of individual actors resulted in a number of schools remaining integrated.

\section{The present-day life of National Schools}

Of the National Schools in this study, many have survived into the twenty-first century as 
viable buildings, centered in the community in new ways (Figure 6). Only a few continue to function as schools (Crossroads and St Eugene's in County Derry, and Killowen and Annsborough in County Down), whereas the majority (13) have become community, heritage or arts centers and one (Lislea) has become an Orange Hall (a venue for a Protestant fraternal organization). The incorporation of such buildings into the fabric of modern-day communities allows their reinvention as social hubs across the lifespan, from establishing mother-and-baby classes and pre-school playgroups to introducing information technology to adults and offering senior citizens' fitness classes. Just over a quarter of the schools included in the study (Ardmillen, Ballynease, Katesbridge, Lisded, the Moat, Monteith, Movanagher and Rossinure) have been converted to dwellings, mostly in rural areas, and only a very small minority has been abandoned and left to deteriorate (Carrickbeg and Drumadonnell).

\section{Conclusion}

National Schools in Northern Ireland (and throughout Ireland) have been used; abandoned to survive only as ruins; re-invented as dwellings, community centers, local museums, and interpretive centers amongst others or incorporated into modern schools. But whatever their fate in the landscape they retain an important place within local history, memory, and culture as embodiments of a sense of community, identity, and place. The ethnographic research undertaken so far in Arney and other locations has shown that the old schoolhouses act as anchors to places and memories and serve as mnemonics for systems of education and daily structures of life. The social life of the buildings as evidenced through the architecture, archaeological investigation, and ethnographic data can reveal the history of practices, attitudes, families, and contemporary attachments to space and place that may act as routes into a rich and varied way of life that has adapted its vernacular architecture or allowed it to remain as reminders in the landscape. Reminiscent of Basso's (1996, pp. 35-70) work on the 
Western Apache and their conceptualization and internalization of the landscape, the schoolhouses also are "stalking with stories". As Henry Glassie (2000, p. 17) argued: "Buildings, like poems and rituals, realize culture."

The examples in this study are only a snapshot of the survival and re-use of National Schools in Northern Ireland and clearly there is much more work to be undertaken, both north and south of the Irish border. The buildings, their records, and their continuing role in the landscape have much to tell of former demographics, the aspirations people had for their children, and past and present community relations. On a wider scale their failures in the past -- where churches competed for control of a secular system and were ultimately successful long before Partition established it as fact -- should inform the direction of future educational initiatives. At a local level, particularly in rural areas, the cross-denominational support for many schools in the past, and the support for this in the present, gives optimism for the future. Many are already functioning in a generalized cross-community setting, but the success of the Arney excavation project suggests that actively focusing on the archaeology and social history of such local buildings -- whether they are above or below ground -- can offer a uniquely positive way of exploring an often painful past. 


\section{Acknowledgments}

The fieldwork at Arney National School was undertaken by the Centre for Archaeological Fieldwork (CAF) at Queen's University Belfast (QUB) on behalf of the Killesher Community Development Association and the Cleenish Community Association. The project was funded by the Heritage Lottery Fund, and was also supported by the Northern Ireland Environment Agency (now the Historic Environment Division of the Department for Communities HED). Thanks are due to Dermot Redmond, Cormac Duffy, Gary Reid, and Paul Clarke who excavated the school, under the direction of Brian Sloan, and to Dr Paul Logue (HED) and Dr Colm Donnelly (QUB) who provided valuable support and advice to the project. Particular thanks are due to all those members of the local community who facilitated and participated in the excavation, especially Barney Devine, Eddie and Ellen Brogan and Myles Keogh. Thanks are due to all the oral history participants for sharing their experiences; to Esther O'Sullivan from the Ulster Architectural Heritage Society for direction to Auld's book on old Holywood; to Ivan Walton for the photograph of Rossinure More; to. Jim and Teresa Quinn for information on Ballynease School and permission to photograph the renovated building; to Kathleen Loughlin, for her memories of Ballynease School; toPhil McCotter for information on Crossroads School; and to Patrick Murphy for sharing the photographs of the schools at Carrickbeg, Lisded, and Tullyholvin. Finally we would like to thank Libby Mulqueeny (QUB) for preparing the final illustrations. 


\section{References Cited}

Akenson, D.H. (1970). The Irish Education Experiment: The National System of Education in the Nineteenth Century. Routledge and Keegan Paul, London.

Appadurai, A. (1986). The Social Life of Things: Commodities in Cultural Perspective. Cambridge University Press, Cambridge.

Auld, J. McC. (2002). Holywood Then and Now: Essays by an Old Resident at the Beginning of a New Millenium. Con Auld, Belfast.

Bardon, J. (2005). A History of Ulster. Blackstaff Press, Belfast.

Basso, K.H. (1996). Stalking with stories. In Basso, K. H. (ed.), Wisdom Sits in Places: Landscape and Language Among the Western Apache. University of New Mexico Press, New Mexico, pp. 19-55.

Beisaw, A.M. (2009). Constructing institution-specific site formation models. In Beisaw. A.M. and Gibb, J.G. (eds), The Archaeology of Institutional Life. University of Alabama Press, Tuscaloosa, pp.49-68.

Booker, J. (1835). 'The system of the National Schools in Ireland considered, in a letter to the Rev. Dr. Sadleir ..., one of the Commissioners of National Education in Ireland.' (1-16) Knowsley Pamphlet Collection. Published by: University of Liverpool: Accessed from http://www.jstor.org/stable/60100440. 
Bourdieu, P. (1977). Outline of a Theory of Practice (trans. R. Nice). Cambridge University Press, Cambridge.

Bourdieu, P. (1979) [1963]. The Kabyle House or the world reversed. In Bourdieu, P. (ed.), Algeria 1960. Cambridge University Press, Cambridge, pp. 133-153.

Carsten, J. and Hugh-Jones, S. (1995). Introduction: About the house: Levi-Strauss and beyond. In Carsten, J. and Hugh-Jones, S. (eds.), About the House: Levi-Strauss and Beyond. Cambridge University Press, Cambridge, pp. 1-46.

Cohen, M. (2000). "Drifting with Denominationalism": A Situated Examination of Irish National Schools in Nineteenth-Century Tullylish, County Down. History of Education Quarterly, 40 (1): 49-70.

Coleman, M.C. (1998). 'Eyes big as bowls with fear and wonder': Children's responses to the Irish National Schools, 1850-1922. Proceedings of the Royal Irish Academy 98C (5):177-202.

Curl, J. S. (2000). The Honourable The Irish Society and the Plantation of Ulster, 1608-2000. Phillimore and Company, Chichester.

Dowling, P. J. (1968). The Hedge Schools of Ireland. Mercier Press, Dublin.

ED/1/22/13. Application for salary to a schoolmaster [Arney] 1849. Public Record Office of Northern Ireland. 
ED/1/22/59. Application for salary to a workmistress [Arney] 1851. Public Record Office of Northern Ireland.

Gieryn, T.F. (2002). What buildings do. Theory and Society 31 (1):35-74.

Glassie, H. (2000). Vernacular Architecture. Indiana University Press, Bloomington.

Hardy, C. (2007). Report 2007:1719 - Rockforest, Tipperary. Excavations.ie Database of Irish Excavation Reports. Available at <http://www.excavations.ie/report/2007/Tipperary/0018708/>

Hyland, A. (1986). Schools and values. Studies: An Irish Quarterly Review 75 (299): 250266.

Hyland, A. and Milne, K. (1987). Irish Educational Documents. Church of Ireland College of Education, Dublin.

Little, B.J. and Shackel, P.A. (2014). Archaeology, Heritage, and Civic Engagement. Left Coast Press, Walnut Creek, CA.

McGlynn, C. (2009). Negotiating cultural differences in divided societies: An analysis of approaches to integrated education in Northern Ireland. In McGlynn, C., Zembylas, M., Bekerman, Z., and Gallagher, T. (eds.), Peace Education and Post-Conflict Societies: Comparative Perspectives. Palgrave Macmillan, Basingstoke, pp. 9-26. 
McKerr, L. (2010). The Archaeology of Children and Childhood in Post-Medieval Ireland. Unpublished Ph.D. thesis, Queen's University Belfast.

McKerr, L. and Murphy, E. (2014). Tales out of school: The 'hidden curriculum' in National Schools in the North of Ireland during the nineteenth and early twentieth centuries.

Childhood in the Past 7(1):49-71.

Mason, W. S. (1814). A Statistical Account, or Parochial Survey of Ireland, Drawn Up from the Communications of the Clergy. John Cumming and Neary Mahon, Dublin.

Markus, T. (1993). Buildings and Power: Freedom and Control in the Origin of Modern Building Types. Routledge, London.

Miller, D. (2010). Stuff. Polity Press, Cambridge.

Navan and District Historical Society (2016). Remembering Dillon's Bridge National School, available at http://www.navanhistory.ie/index.php?page=dillons-bridge-national-school

Oliver, P. (1969). Shelter and Society. Barrie and Rockliff, London.

Oliver, P. (1987). Dwellings: The House Across the World. University of Texas Press, Austin.

Oliver, P. (2003). Dwellings: The Vernacular House Worldwide. Phaidon Press, London.

Oliver, P. (2006). Built to Meet Needs: Cultural Issues in Vernacular architecture. 
Architectural Press, Oxford.

Porter, J. L. (1871) [1999]. The Life and Times of Henry Cooke. Ambassador Publications, Belfast.

Public Record Office of Northern Ireland [PRONI] (2015). List of school records arranged by parish. Accessed from

http://www.proni.gov.uk/index/research_and_records_held/catalogues_guides_indexes_and_1 eaflets/online_guides_and_indexes.htm.

Raftery, D. and Relihan, M. (2012). Faith and nationhood: Church, state and the provision of schooling in Ireland, 1870-1930. In Brockliss, L. and Sheldon, N. (eds.), Mass Education and the Limits of State Building 1870-1930. Palgrave Macmillan, Basingstoke, pp. 71-88.

Rathbone, S. (2007). Report 2007:1365 - Philpotstown 3, Meath. Excavation. Database of Irish Excavation Reports. Available at http://www.excavations.ie/report/2007/Meath/0018342/

Robins, J. (1987). The Lost Children: A Study of Charity Children in Ireland 1700-1900. Institute of Public Administration, Dublin.

Rotman, D.L. (2009). Rural education and community social relations: Historical archaeology of the Wea View Schoolhouse No.8, Wabash Township, Tippecanoe County, Indiana. In 
Beisaw, A.M. and Gibb, J.G. (eds), The Archaeology of Institutional Life. University of Alabama Press, Tuscaloosa, pp. 69-85.

Rowan, A. J. (1979). North West Ulster: The Counties of Londonderry, Donegal, Fermanagh and Tyrone. Harmondsworth, New York.

Sayers, P. (1974) Peig: The Autobiography of Peig Sayers of the Great Blasket Island (trans. Bryan McMahon). Talbot Press, Dublin.

Ulster Towns Directory (1910). Holywood, Co. Down. Accessed from http://www.libraryireland.com/UlsterDirectory1910/Holywood.php

Walsh, P. (2008). Education and the 'universalist' idiom of empire: Irish National School books in Ireland and Ontario. History of Education, 37(5): 645-660.

Vellinga, M. (2014). 'Built to meet needs': Paul Oliver and the study of vernacular architecture. In Correia, M., Carlos, G. and Rocha, S. (eds.), Vernacular Heritage and Earthen Architecture: Contributions for Sustainable Development. Taylor and Frances, London, pp. 3-7.

Vellinga, M. (2005). Anthropology and the challenge of sustainable architecture. Anthropology Today 21 (3):3-7. 